\title{
The Secular Trend of Brazilian Terms of Trade Revisited - 1850 to 2000
}

\author{
Sérgio Kannebley Jr.*
}

\author{
Amaury Patrick Gremaud **
}

\begin{abstract}
The purpose of this paper is to revisit the commonly argued secular deterioration of the Brazilian terms of trade using structural time series models. We argue that the ambiguity observed in previous studies about this topic is due to the lack of generality of the statistical specification. Specifically, the trend component used in those studies does not nest alternative specifications. Additionally, these representations do not allow multiple breaks and/or outliers. Diagnostic tests and forecasts suggest the superiority of the random walk with drift representation, in the presence of multiple breaks. The results obtained indicate the existence of a negative deterministic slope between the period of 1850 and 2000.
\end{abstract}

\section{Resumo}

O objetivo deste artigo é reavaliar a tese da deterioração secular dos termos de troca para a economia brasileira, por meio da estimação de modelos estruturais de séries de tempo. Argumenta-se aqui que uma parcela da ambigüidade dos resultados apresentados pela literatura empírica sobre o tema deveu-se à não generalidade das representaçōes estatísticas utilizadas. Estas representaçōes falharam em permitir a incorporação, de modo conjunto, de diversas possibilidades de representação do componente de tendência, além de quebras estruturais e/ou outliers. Testes de diagnósticos e a comparação do poder preditivo fora da amostra sugerem a superioridade da representação random walk com drift, adicionado de múltiplas quebras estruturais para a série de termos de troca brasileiros. Com isso, foi possível inferir a presença de um termo de inclinação determinista negativo para a série do Brasil, no período de 1850 a 2000.

\footnotetext{
${ }^{*} \mathrm{PhD}$ and professor, FEA/RP-USP

${ }^{* *} \mathrm{PhD}$ and professor, FEA/RP-USP and PROLAM/USP
}

Brazilian Review of Econometrics Rio de Janeiro v.23, $\mathrm{n}^{\mathrm{O}_{1}, \text { pp.111-142 May } 2003}$ 
The Secular Trend of Brazilian Terms of Trade Revisited - 1850 to 2000

Key Words: Brazilian terms of trade, structural models, trade and development .

JEL Code: O19.

\section{Introduction.}

After economic stabilization and at least ten years of structural reforms, the Brazilian economic problems in need of immediate solution are the external balance and the recovery of the sustained economic development. Both issues are directly associated with the future behavior of the Trade Balance, which reflects the export capacity of the Brazilian economy.

The growing inflow of foreign savings throughout the 1990s brought on increasing international burdens for the future. In this regard, an important aspect is to know to what extent the inflows that have been invested according to a new pattern of economic development, based on trade and financial openness, will be turned into foreign currency revenues as a result of a Brazilian export boom, since the inflow of foreign savings cannot be maintained ad eternum.

One of the interesting facets to this discussion involves the formulation of an economic development model, which by means of the implemented economic reforms, seems to relinquish Brazil's classic economic development model based on import substitution. Conceptually, this issue is discussed in Krueger (1997), who critically reviews the debates over and the investigation into the presuppositions that used to support inner-oriented development models ${ }^{1}$. One of these presuppositions is the well-known thesis by Prebisch-Singer [Prebisch (1950) and Singer (1950)] about the secular deterioration of the terms of trade. This thesis is an excellent object for reassessment given the expectations built around the performance of the

\footnotetext{
${ }^{1}$ For further details about the discussion, see Krueger (1997), Rodriguez \& Rodrick (1999), and Srinivasan \& Bhagwati (1999).
} 
Brazilian trade balance in the future, and the relationship between "export pessimism" and the creation of a new economic development model for Brazil".

The aim of the present article is to reassess the thesis on the deterioration of the terms of trade for the Brazilian economy through the estimation of structural time series models. This category of models allows incorporating some of the major criticisms about conventional econometric procedures described in the literature to test out the same hypothesis. Aside from this introduction, the article consists of six sections. Section two briefly reviews the literature regarding Prebisch-Singer hypothesis. The third section discusses the alternative representations to the trend component of the terms of trade and how these representations are nested in the local linear trend model. Section four statistically analyzes the terms of trade series, including a historical analysis, which seeks to recall some facts that marked the evolution of the Brazilian terms of trade. Section five describes the model proper and the estimations performed, presenting some final considerations.

\section{Brief Literature Review.}

The discussion about the secular trend of terms of trade in the postwar period focused on the asymmetric relationship between developed countries (center) and underdeveloped or developing countries (periphery). This discussion is often associated with PrebischSinger hypothesis [Prebisch (1950), Singer (1950)], in which the trade relations between developed and developing countries encompass a structural dualism. In other words, the existence of structural differences between these economies produces a set of asymmetric trade

\footnotetext{
${ }^{2}$ The works by Iglesias (2001) and Kannebley Jr. (2002), among others, are examples of current discussions about Brazilian export difficulties.
} 
relations, given by an international specialization pattern that results in the secular deterioration of terms of trade around the periphery.

Originally, Prebisch-Singer hypothesis refers to the terms of trade between primary goods, produced by underdeveloped economies, and manufactured goods, from industrialized economies. Singer (1987) points out the following factors as possible causes for the secular deterioration of the terms of trade: i) different price elasticities of demand for primary and manufactured goods, ii) different income elasticities of demand, iii) technological superiority of developed countries and iv) different structures of goods and job markets.

Even if these arguments are applicable to the different productive sectors of a country, or if we consider that unemployment-related problems do not affect developing countries only, we should note that the discussion about the deterioration of the terms of trade is primarily focused on the different features of developed and developing countries (or center and periphery), rather than on the types of traded goods.

Since the formulation of Prebisch-Singer hypothesis there has been a growing shift towards the industrialization of developing countries, but it has not yet allowed the elimination of asymmetries between these two types of countries.

In this regard, the literature about the relationship between advanced (North) and less developed (South) economies evolved into the creation of growth models and determination of terms of trade that could take into account the existence of asymmetries and the dependence of less developed countries upon developed ones. Among the several models that include this type of relationship, as those presented in Findlay (1981), the so-called North-South models are more prominent.

In this category of models, we have the works by Findlay (1980), 
Darity (1990) and Sarkar (1997). However, it is not possible to demonstrate that the inelasticity of demand for southern products accounts for the secular decline in the terms of trade, whereas the mark-up increase (or monopoly level) in the North yields ambiguous results. On the other hand, the technical progress and the relative income inelasticity of demand for southern products, in some models, are able to explain the decreasing secular trend of the terms of trade.

The statistical evidence regarding this discussion is ambiguous. Spraos (1980) examines a body of statistical evidence for and against Prebisch-Singer hypothesis, where problems with transportation costs and changes in quality are involved. Recently, Sarkar and Singer (1991) have found evidence of a decline in the unit values of periphery manufactured exports vis-à-vis center manufactured exports for the period between 1970 and 1987. These results are questioned in Athukorala (1993), where it is argued that the aforementioned authors did not give enough attention to the necessary data correction. Barros (1992) mentions a set of representative studies on this topic, among which the empirical works recently conducted by Grilli and Yang (1988), Cuddington and Urza (1989), Diakosavvas and Scandizzo (1991) are of special interest. Most of these studies tested the hypothesis of deterioration of relative price index series for primary goods.

\section{A Local Linear Trend Model and Local Level Model and the Alternative Representations for the Deteriorating Trend of Brazilian Terms of Trade.}

The local linear trend model is a general model for the trend component, which, in addition to a stochastic component $\mu_{t}$, also includes a stochastic slope component $\beta_{t}$, both following a random walk process. Therefore, we have: 
The Secular Trend of Brazilian Terms of Trade Revisited - 1850 to 2000

$$
\begin{aligned}
y_{t}=\mu_{t}+\eta_{t}, & \eta_{t} \sim \operatorname{NID}\left(0, \sigma_{\eta}^{2}\right) \\
\mu_{t}=\mu_{t-1}+\beta_{t-1} \varepsilon_{t} & \varepsilon_{t} \sim \operatorname{NID}\left(0, \sigma_{\varepsilon}^{2}\right) \\
\beta_{t}=\beta_{t-1}+\delta_{t} & \delta_{t} \sim \operatorname{NID}\left(0, \sigma_{\delta}^{2}\right)
\end{aligned}
$$

where $\eta_{t}, \varepsilon_{t}$ and $\delta_{t}$ are uncorrelated disturbances.

According to Barros (1992) it is not possible to clearly distinguish which model underlies the formulation of Prebisch-Singer hypothesis for the deteriorating secular trend of the terms of trade. Two formulations are widely used ${ }^{3}$. The first formulation, usually tested in the empirical literature on the topic, is the one in which the trend is deterministic. In other words, the case in which both variances $\sigma_{\varepsilon}^{2}$ and $\sigma_{\delta}^{2}$ are null, such that (1) is reduced to:

$$
\mu_{t}=\mu_{0}+\beta t \quad \text { for } \quad t=1,2, \ldots, T
$$

A second possibility would be a random-walk-with-drift model, in which parameter $\beta$ is constant and negative, $\beta<0$. This occurs when only $\sigma_{\delta}^{2}$ is equal to zero, such that (1) is reduced to:

$$
\mu_{t}=\mu_{t-1}+\beta+\varepsilon_{t}
$$

Most studies that test out the hypothesis of deteriorating trends for the Brazilian terms of trade series use econometric specifications that correspond to equation (1.a) shown above. These are the studies carried out by Gonçalves and Barros (1982), Souza (1984) and Zini Jr. (1988). They attempt to test the hypothesis of deterioration

${ }^{3}$ Barros (1992) also presents a possible third representation in which there exists a deteriorating quadratic trend aside from a deteriorating linear trend. However, this statistical model seems poorly representative of the historical facts presented by the Brazilian terms of trade series, as can be seen in section 4 . 
of the terms of trade with regard to the existence of a negative deterministic trend, disregarding the possibility of the series having a unit root, that is, the existence of a stochastic trend. Even the work conducted by Souza (1984), which incorporates an autoregressive component into the model, hypothetically assumes the stationarity of the series.

Gonçalves and Barros (1982) try to prove Prebisch thesis about the terms of trade index series for the period between 1850 and 1979. These authors estimated a semi-logarithmic equation for the whole period and found a negative trend coefficient with significance at $5 \%$. By using the same model, Zini Jr. (1988) also obtained a coefficient for the negative time trend term with significance at $5 \%$, for the 1860-1986 period, which was considered to be a piece of evidence in favor of Prebisch-Singer hypothesis. On the other hand, Souza (1984) conducted an alternative study to the terms of trade series used in Gonçalves and Barros (1982) and reassessed some of their results. By estimating a more general model, the author concluded that the thesis of secular deterioration of the terms of trade should not be validated. Statistically speaking, it is possible to perceive by the statistics obtained by Durbin-Watson for the models introduced by Gonçalves and Barros (1982), and by Zini Jr. (1988), who does not report it but only informs about its low value, that these models have specification problems, which are particularized in Souza (1984) ${ }^{4}$.

Gonçalves and Barros (1982) still stress that their results should be qualified when specific subperiods are analyzed. The authors

\footnotetext{
${ }^{4}$ The weak time series stationarity may be achieved by differentiation of the series, if this series has a stochastic trend, which characterizes it as stationary difference. If the series is turned into stationary by the extraction of the deterministic trend, this type of series is called stationary trend. The subtraction of a deterministic trend from a stationary series is an inappropriate process, since the stochastic trend is not eliminated, resulting in high autocorrelation of residuals, as observed in the models designed by Gonçalves and Barros (1982) and Zini Jr. (1988).
} 
affirm that the period with greater deterioration was exactly the one analyzed by Prebisch (1870-1939), where a coefficient associated with the trend term was observed, with a value that closely resembled the one presented in Spraos (1980). Subperiods in which the deterioration was rejected were also found, for instance, 1850-1913, 1913-1979 and 1945-1979. Gonçalves and Barros (1982) employed a "historical" method to identify the trend changes to the series, analyzing specific subperiods in view of relevant historical facts and/or periods. Souza (1984), however, defines three historical subperiods, namely 1850-1887, 1887-1940, 1940-1979, which describe changes to this component by means of the extraction of the trend component from the terms of trade ${ }^{5}$. The adjustment of a linear model with the use of dummy variables to test the different subperiods produces significant estimates which show that in two subperiods (first and third) the deteriorating trend does not occur, and that only in one subperiod (the second one) a strongly negative trend is observed.

The possibility of a stochastic trend in the terms of trade series, established according to equation (1.b), was first considered by Zini Jr. and Cati (1991). These authors, in a cointegration analysis between real exchange rate and terms of trade, performed an ADF unit root test for the Brazilian series of terms of trade in the 18551990 period, and found evidence in favor of the non-rejection of the unit root hypothesis in the series and conditions for the existence of a deteriorating trend ${ }^{6}$. Marçal (1996), by using the method introduced by Perron (1989) for the estimation of a unit root test in the presence of a structural break in the series, rejects the hypothesis

\footnotetext{
${ }^{5}$ The author uses a linear filter (moving averages) to eliminate irregularities and extract the cyclic component from the series.

${ }^{6}$ Zini Jr. and Cati (1991) did not intend to check the deteriorating trend of the terms of trade, but only wanted to present the statistical values for the hypothesis tests. However, by observing the critical values found for the deterministic components of the ADF model, it is possible to infer about the deteriorating trend of the terms of trade.
} 
of structural change to both the trend and the level of successively tested years ${ }^{7}$. The application of Perron's test (1989) yielded results that are not different from those obtained by Zini Jr. and Cati (1991) with regard to the presence of a unit root. Nevertheless, by introducing a deviation of the means towards 1912, we obtain a coefficient for the deterministic term of the statistically insignificant model, at $10 \%$, producing some evidence against the study developed by Zini Jr. and Cati (1991) regarding the deteriorating trend of the terms of trade. Table 1 summarizes the results obtained through these studies and the different models that were estimated.

\section{Table 1}

Summary of Evidence regarding the Trend of Brazilian Terms of Trade

\begin{tabular}{|c|c|c|c|c|c|c|}
\hline Author & Period & & Joefficients & & $\mathrm{R}^{2}$ & DW \\
\hline & & $\alpha$ & $\beta$ & $\phi$ & & \\
\hline $\begin{array}{l}\text { Gonçalves\& } \\
\text { Barros(1982) }\end{array}$ & 1850-1979 & 4.849 & -0.0028 & - & 0.130 & 0.32 \\
\hline Zini Jr.(1988) (1) & $1860-1986$ & 5.420 & -0.004 & - & 0.18 & - \\
\hline Souza(1984) (2) & $1850-1979$ & 23.72 & -0.06 & 0.82 & 0.72 & - \\
\hline Marçal(1996) (3) & $1855-1990$ & 1.292 & -0.00092 & 0.73 & - & 2.03 \\
\hline
\end{tabular}

The estimates models are:

(1) $1 n Y_{t}=\alpha+\beta t+\varepsilon_{t}$

(2) $Y_{t}=\alpha+\beta t+\phi Y_{t-1}+\varepsilon_{t}$, with $|\phi<1|$

(3) $Y_{t}=\alpha+\beta t+\phi Y_{t-1}+\gamma D(T B)+\delta D u_{t}+\sum b \Delta Y_{t-i}+\varepsilon_{t}^{8}$

${ }^{7}$ The selection of the moment for structural change occurs through the sequential date test, by choosing a date on which the $t$ statistics $(\phi)$ for the unit root test is maximized. For the case studied here, the years 1905 to 1920 were tested, and the $t$ statistics $(\phi)$ was maximized in 1912 . ${ }^{8}$ where $D(T B)=0$ if $t \neq T B$ and 1 if $t=T B ; D u=0$ if $t<T B$ and $I$ if $t>T B$ and $T B=$ break year. 
Therefore, the conclusion about the evidence gathered by the studies on Brazilian terms of trade is that there are some ambiguous results due to the different hypotheses that underlie the data generating process of the Brazilian terms of trade series and due to the different econometric procedures used. Despite the possible statistical problems that result from the construction of the series, the studies above show particular characterizations for the secular trend component, combined, in some cases, with statistical procedures, or ad hoc, for the determination of structural breaks of the series. While the studies conducted by Gonçalves and Barros (1982) and Souza (1984) presuppose a linear trend, allowing for the presence of multiple structural breaks, determined ad hoc, Zini Jr. and Cati (1991) and Maral (1996) consider the hypothesis of a stochastic trend, but only Maral (1996) jointly permits the test for the trend component and the estimation for a single structural break by means of an endogenous procedure for the determination of structural break.

\section{The Behavior of Brazilian Terms of Trade - $1850-2000$.}

The Brazilian historical series concerning the terms of trade indices, price of imports and exports for the period between 1850 and 2000 were elaborated from the data presented by the Brazilian Institute of Geography and Statistics (IBGE, 1990) for the period comprised between 1850 and 1979, updated until the year 2000 from the data of FUNCEX (Center for Foreign Trade Studies). Graph 1 shows the analysis of the logarithm series of the Brazilian terms of trade. The correlogram and the spectrum of the series show a high concentration of variation in the series at low frequencies, indicating the presence of a cyclic component, in addition to the possible existence of a stochastic or deterministic trend. The CUSUM statistic indicates the alteration to the mean of the series at the end of the 19th century, stabilizing again around 1950. The CUSUM of 
squares statistic does not report change in variance, suggesting a homoskedastic model for the series. The empirical distribution of the series shows clear leftward asymmetry, suggesting non-normality of the series, in agreement with the CUSUM statistic.

\section{Graph 1}

Statistical Analysis of the Brazilian Terms of Trade Series
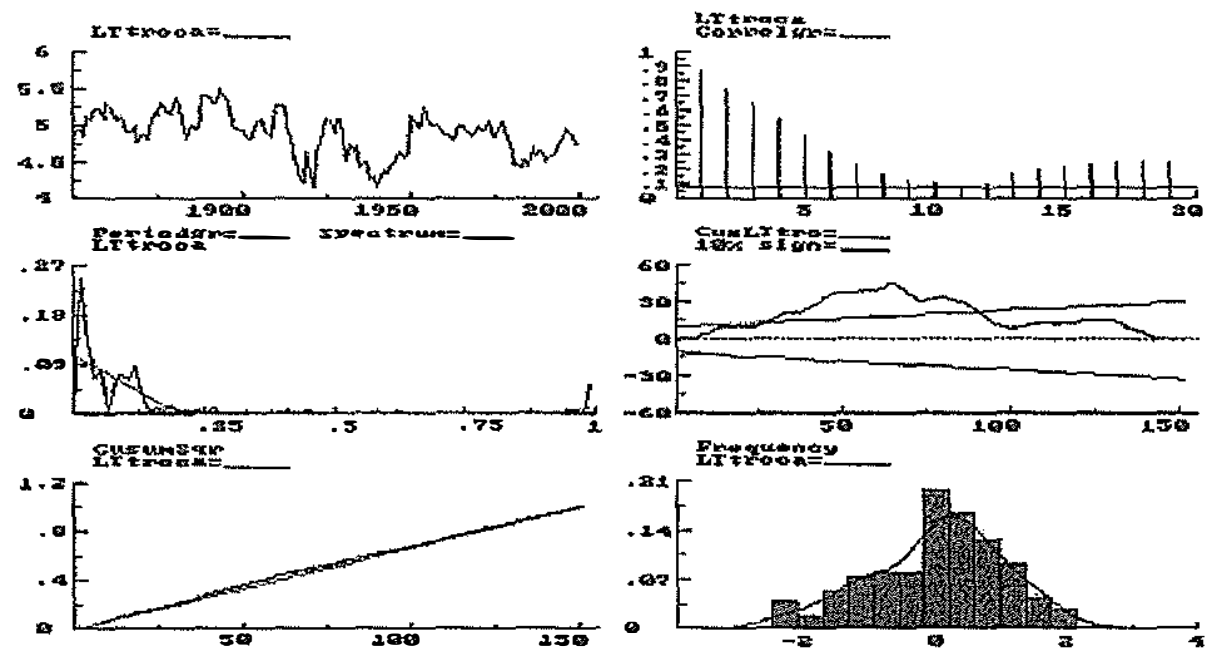

The interpretation of these statistical characteristics of the historical series may be made by primarily observing that the existence of a cyclic pattern is based upon remarkable historical evidence described by several authors, such as Delfim Netto $(1966)^{9}$ and Bacha (1982). It is possible to perceive that the terms of trade series in the 19 th century presented a cyclic pattern, which corresponds to coffee price cycles studied by Delfim Netto (1966). The secular trend of

\footnotetext{
${ }^{9}$ The importance of coffee price evolution for the terms of tradeseries is given by the importance of coffee in the Brazilian export list, which is kept high until the 1970s.
} 
the international coffee price in this period is controversial. Delfim Netto (1966) points to the nonexistence of trend between 1857 and 1906; in this period, only three coffee price cycles in a market without governmental intervention are observed ${ }^{10}$. Bacha (1982), on the other hand, describes a positive secular trend for the coffee price between 1845 and $1895^{11}$, as a result of market disequilibrium, where the supply could hardly keep up with the highly dynamic demand. This restriction is explained both by the problems with workforce shortage and the elevated transportation costs.

The last of the three coffee cycles studied by Delfim Netto (1966) shows differentiated characteristics: its length and decrease are longlasting, which is traditionally explained by the effects of monetary and exchange rate policies adopted in the 19th century's last decade on the behavior of the price of exports ${ }^{12}$. Again, Bacha (1982) gives a different explanation: the decrease in prices after 1895 is due to the reversion of the aforementioned disequilibrium, which occurred because of the growth of coffee production in the western region of the state of São Paulo, now without the mentioned restrictions.

In the terms of trade series, it is possible to infer a not so clearly defined pattern for the period that corresponds to the third coffee price cycle as that for the other two cycles and also an increase in the mean. The increase in the terms of trade from 1888, especially, is

\footnotetext{
${ }^{10}$ The coffee price cycles analyzed by Delfim Netto were: $1857-1868 ; 1869-1885$ and $1886-1906$.

${ }^{11}$ Bacha uses as reference a period that precedes the one analyzed by Delfim Netto, in which the prices were usually lower than those observed in 1857, initially obtained by Delfim. In addition, Bacha's series ends before (Delfim in 1906 and Bacha in 1895), avoiding the period of price falls of the last cycle before governamental intervention.

${ }^{12}$ Aside from Delfim's, we can also cite the works by Furtado (1959), Fausto (1975), Franco (1983) with special emphasis on the positive impacts of the Encilhamento on the growing of new coffee plants.
} 
higher than the previous cyclic elevations. In fact, the increase in the price of exports in this period is different from the one that occurred in previous cycles, which were partly compensated for the rise in the price of imports. Until 1895, we observe a period of increase in the terms of trade in function of the rise in the price of coffee and of the decrease in the price of imports, the so-called period of the manufactured product price dip (Gonçalves and Barros, 1982) ${ }^{13}$. After this period, the terms of trade follow a downward path, due to the fall in the price of coffee as a result of the previously mentioned expanded coffee production in the state of São Paulo.

The possible alteration to the mean of the series therefore occurs at the end of the 19th century. Until the mid-20th century the series is characterized by a quite erratic behavior. In general, we may say this is a truly problematic period since there was a large international crisis, two world conflicts, in addition to a more restricted one - the Korean War - which also brought about remarkable effects on the international trade prices. Nationally speaking, Brazilian exports maintained their high level of coffee exportation, despite the implementation of the internationalization process. The coffee market, however, after the first decade of the century suffers some interventions, with stock retention (and its physical destruction after 1930), from the Brazilian government. According to Bacha (1982), Brazil's intervention in the coffee market does not cause the cyclic pattern of the price series to disappear, but it enhances it instead.

After the government began to intervene in the coffee market, an increase in the terms of trade was observed, but right before World War I a strong decrease had been felt in the series. Such decrease

\footnotetext{
${ }^{13}$ The rise in export prices in this period may also be partly explained by the end of the longlasting international recession installed in 1873.
} 
resulted from the upward trend (prior to the war) of import prices and from the steep reduction of rubber prices (entry of Southeastern Asia into the market) at the beginning of the 1910s and of coffee prices in 1913. Such tendency towards deterioration is maintained throughout World War I, with a relatively higher increase in the price of imports than that which occurred with the price of exports. Only at the end of the war, in 1919, there was a shock to the price of exports, which was reversed in the following two years. Likewise, the price of imports slumped in the postwar period.

The price of imports slumped further in 1921 and 1922, whereas the price of exports rose thereafter. During that decade, after the 1922-1924 increase, the situation stayed relatively stable regarding the terms of trade. However, the 1930 crisis meant a new shock to the terms of trade series, with a sharp reduction in the price of exports (especially of coffee) in 1930, caused by a decrease in demand and by Brazil's stepped-up production as well. The prices deteriorated further in the subsequent year, also including the price of imports. The decade was marked by several fluctuations in the series of import and export prices, but, in general, there was an apparent tendency towards the deterioration of the terms of trade until 1940, which still reflected the disequilibrium of the coffee market and the effect of monetary and political misadjustments of the period.

During the war, international agreements supported the elevation of Brazilian export prices, which happened at a faster pace than that of imports. In the postwar period, however, we can clearly observe a new shock to export prices at the end of the 1940s, especially in 1950, in the imminence of the Korean War. This shock resulted from a new disequilibrium in the coffee market. This time there was lack of supply because of the reduced Brazilian production, in 
addition to a reduction in international stocks, which ran out along the 1940s. Interestingly enough, if we compare the price of coffee to other primary products, we note that such a strong price shock did not involve any other commodities ${ }^{14}$. This increase in the price of exports is not immediately followed by an increase in the price of imports, which was deteriorating at the end of the 1940s and began to rise, at a lower pace, in the early 1950s, right after the price of exports. As from 1953, the price of imports started to fall again; this reduction only involved the price of exports from 1955 onwards, thus giving rise to a new phase of deterioration of the terms of trade. In the 1960s, the price of imports showed a slight upward tendency, which also occurred with exports, with two pronounced increases in 1963 and 1969, reflecting problems with coffee supply, in spite of the diversification of the export list.

In the 1970s, with the intensification of the import substitution process, the participation of manufactured products in the Brazilian export list was encouraged. From 1974 to 1980, the participation of manufactured goods in the export list went from $28.6 \%$ to $44.8 \%$. At the end of the 1980s, this participation reached $54.2 \%$ of the total amount of exports. On the other hand, the participation of basic products in the export list decreased: it went from $57.6 \%$ in 1974, to $42.2 \%$ in 1980 , reaching up to $27.8 \%$ at the end of the 1980 s. These percentages remained relatively stable in the 1990s. This process of alteration to the export list caused the Brazilian terms of trade to be less sensitive to striking variations of agricultural commodities.

\footnotetext{
${ }^{14}$ Perhaps, because of this positive shock exclusively resting on coffee production that some analyses of the evolution of the terms of trade show the different behavior of the series highly influenced by tropical beverages, as is the case of Brazilian coffee, from those reliant on other commodities. According to Grilli and Yang (1988), the thesis on the deterioration of the terms of trade is confirmed for the latter but not for the former series.
} 
From this moment on, the greatest oscillations in the terms of trade were caused by the variation in the price of imports, especially, due to the first and second oil price shock, in 1973 and in 1979, respectively. Both had an effect on the terms of trade, but the second shock was more remarkable. A strong deterioration of the terms of trade is observed, which began before 1978 and lasted until 1983, but we should not forget that these years also represent periods of international recession. With regard to the price of exports, after an increase at the beginning of the 1970s, it had a relatively stable trajectory until the mid-80s. However, the price of primary products showed a downward tendency after the second half of the 1970s, which lasted more or less until the mid-90s. On the other hand, the price of manufactured export products revealed a slightly upward movement. As from the mid-90s, the terms of trade entered a new phase of decline, mainly as a consequence of the reduction in the price of exports, and stabilized in the year 2000 at a lower level than they did in the year of 1996.

\section{Econometric Methodology and Results .}

As discussed in section 2, the studies that attempt to test out the hypothesis of secular deterioration of the Brazilian terms of trade lack a unified statistical treatment. Such treatment should allow estimating the stochastic and/or deterministic trend component, in addition to estimating multiple structural breaks, as suggested by Gonçalves and Barros (1982) and Souza (1984), besides the unobservable and irregular cyclic components as observed by Souza (1984). To accomplish this task it is necessary to adopt a sufficiently general statistical representation. This statistical representation is provided by a structural model based on a local linear trend model, accompanied by a 
cyclic component. With the estimation of this sufficiently general model, associated with a statistical procedure for the detection of structural breaks and outliers, it is possible to produce statistically adequate models by means of a process of reduction of this model towards a particular specification case of trend term, without establishing a priori any form for the data generating process.

The statistical treatment of structural time series models is based on the state-space form (S.S.F.). Once in SSF, the Kalman filter may be applied, which takes to prediction and smoothing algorithms ${ }^{15}$. In a Gaussian model, the estimation is made through Kalman filter, using a likelihood function based on the decomposition of the prediction error. The SSF for the estimated model is as follows:

$$
\begin{gathered}
y_{t}=Z_{t} \gamma_{t}+\varepsilon_{t} \quad \text { (measurement equation) } \\
\gamma_{t}=T_{t} \gamma_{t-1}+R_{t} \xi_{t} \quad \text { (transition equation) }
\end{gathered}
$$

in which the elements of $\gamma_{t}$ are the unobservable components of the model, $\varepsilon_{t}$ is a white noise term and $\xi_{t}$ is a vector of white noise components that are uncorrelated between themselves and not correlated with $\epsilon_{t}$, whereby $\epsilon \sim N\left(0, \sigma_{\epsilon}^{2}\right), \xi_{t} \sim N(0, \Omega)$. The set of parameters given by matrices $T$ and $\Omega$ are called hyperparameters of the model. The vector of unobservable components consists of a stochastic trend and a stochastic cyclic component, that is:

\footnotetext{
${ }^{15}$ Kalman filter is a recursive procedure for calculating the optimal estimator of the state-space vector, given all the information available up to the current moment. A backward recursion is known as smoothing and allows the state-space vector to be calculated at all points of time by using the entire sample. For further details about the estimation of time series structural models, see Harvey (1989).
} 
The Secular Trend of Brazilian Terms of Trade Revisited - 1850 to 2000

$$
\gamma_{t}=\left[\begin{array}{c}
\mu_{t} \\
\beta_{t} \\
\varphi_{t} \\
\varphi_{t}^{*}
\end{array}\right]=\left[\begin{array}{cccc}
1 & 1 & 0 & 0 \\
0 & 1 & 0 & 0 \\
0 & 0 & \rho \cos \lambda_{c} & \rho \operatorname{sen} \lambda_{c} \\
0 & 0 & -\rho \operatorname{sen} \lambda_{c} & \rho \cos \lambda_{c}
\end{array}\right]\left[\begin{array}{c}
\mu_{t-1} \\
\beta_{t-1} \\
\varphi_{t-1} \\
\varphi_{t-1}^{*}
\end{array}\right]+\left[\begin{array}{c}
\eta_{t} \\
\delta_{t} \\
\kappa_{t} \\
\kappa_{t}^{*}
\end{array}\right]
$$

Based upon the smoothed estimates of the models standardized disturbances, defined as standard innovations, we carry out diagnostic tests for the detection of outliers and structural breaks according to the procedure proposed by Harvey and Koopman (1992).

As previously argued, the strategy for the estimation of structural models will be from the most general model to the most specific one. Therefore, the first estimated model was the one of local linear trend with a cyclic component. The inclusion of this last component is justified by the information found on the estimated correlogram and spectrum, in addition to the historical description of the previous series.

In the first round of estimation of the model (2), for the period between 1850 and 2000, the estimated hyperparameters, shown in Table (2), show that the slope component has null variance, which indicates a deterministic term. On top of that, the diagnostic tests indicate that the residuals calculated for this specification violated the hypothesis of normality and absence of autocorrelation, revealing additional specification problems related to the presence of outliers and/or structural breaks. 
Sérgio Kannebley Jr. and Amaury Patrick Gremaud

Table 2

General Structural Model-Estimated Hyperparameters

\begin{tabular}{lll}
\hline Component & Standard deviation & Q ratio \\
\hline Irregular & 0.0616601 & 0.6829 \\
Level & 0.0578986 & 0.6412 \\
Slope & 0.00000 & 0.0000 \\
Cycle & 0.0902907 & 1.0000
\end{tabular}

Diagnostic Statistics

$\begin{array}{lllll}\text { SD } 0.14489 & \mathrm{H}(49) & 0.6863 & \mathrm{DW} & 1.949\end{array}$
$\mathrm{r}(1)$
0.022706
$\mathrm{r}(11)$
$-0.19982$
$\mathrm{Q}(11.10)$
$14.68[0.0229]$
$\mathrm{R}^{2}$
0.7545
$\mathrm{Rs}^{2}$
0.066144

Asymmetry $\mathrm{Chi}^{2}(1): 5.6122$ [0.0178] Kurtosis $\mathrm{Chi}^{2}(1): 9.6224$ [0.019]

Normal-BS Ch${ }^{2}(2) ; 15.235$ [0.0005] Normal-DH Chi' ${ }^{2}(2): 9.5134$ [0.0086]

Statistics $\mathrm{H}(\mathrm{h})$ refers to the heteroskedasticity statistical test, statistics $\mathrm{r}(\mathrm{j})$ refer to the autocorrelations of the residuals, $Q(p, q)$ is the Ljung-Box statistics, D.W. is Durbin-Watson statistics, N-DH, Doornik and Hansen normality test, N-BS, Bowman and Shelton normality test.

Restricting $\sigma_{\delta}^{2}=0$ and using Harvey and Koopman (1992) procedure, table 3 presents the outliers and structural breaks found for various dates, all of which were within the time interval comprised by 1888 to $1954^{16}$. As demonstrated by the normality tests, the auxiliary residuals violate the hypothesis of normality initially assumed in the model (2). These results are also consistent with the first descriptive analysis for the presented series, when by means of the

\footnotetext{
${ }^{16}$ The detection of outliers and structural breaks on the estimation of the irregular component of the model and of the auxiliary residuals, which are estimates of the stochastic component of the level series.
} 
The Secular Trend of Brazilian Terms of Trade Revisited - 1850 to 2000

CUSUM statistic, instability was detected in the mean of the series for the period between 1885 and $1950^{17}$.

\section{Table 3}

Dates of Outliers and/or Structural Breaks

\begin{tabular}{llllll}
\hline Irregular & Value & Probability & Level & Value & Probability \\
1919 & 3.6622 & {$[0.0005]$} & 1913 & -2.0241 & {$[0.0224]$} \\
1929 & 2.2085 & {$[0.0144]$} & 1919 & 2.2597 & {$[0.0126]$} \\
1930 & -2.0042 & {$[0.0234]$} & 1920 & -2.3760 & {$[0.0094]$} \\
1949 & -2.0421 & {$[0.0214]$} & 1922 & 2.3314 & {$[0.0105]$} \\
1950 & 2.8187 & {$[0.0027]$} & 1930 & -3.1696 & {$[0.0009]$} \\
1954 & 2.0422 & {$[0.0214]$} & 1950 & 3.8224 & {$[0.0001]$} \\
& & & 1954 & 2.1586 & {$[0.0162]$} \\
& \multirow{2}{*}{ Normal-BS } & 8.0983 & & Normal-BS & 10.9047 \\
& Chi $^{2}(2)$ & {$[0.02]$} & & Chi $^{2}(2):$ & {$[0.004]$} \\
\hline
\end{tabular}

Table 4 shows the modeling with the best results in terms of quality of the residuals and stability of the model, aside from its adjustment capacity, given by AIC and BIC statistics. This model consists of a stochastic level term, combined with a deterministic slope and a stochastic cycle, in addition to irregular and level interventions. These estimated components are shown in graph 2 . The estimated cycle has a period of 19.97 years, corresponding to a frequency of 0.3146. Furthermore, the importance of the stochastic character of the cyclic component should be emphasized, since it

\footnotetext{
${ }^{17}$ The prevalence of agricultural products in the Brazilian export list until the mid-1960s and the greater variability of their prices in relation to the prices of manufactured products is the possible reason for the detection of outliers and structural breaks up to 1954. The oil price shock in the early 1970 s represented a variation in the terms of trade relatively lower than those produced by the variations in the agricultural prices, being incorporated by the model into the stochastic term of the cyclic component.
} 
permits incorporating changes to the cyclic behavior of the series over different periods, such as those at the end of the 19th century and during the 20th century. The influence of the modeling of various interventions is also important, since they portray the moments of structural breaks in the series, which are the key components in the alteration to the terms of trade ${ }^{18}$.

Notably, the slope of the terms of trade is statistically significant at $6 \%$, and the estimated coefficient has a negative signal, with a value of -0.006 . When the series is modeled, the neperian logarithm of the terms of trade expresses the annual decline rate. These results therefore reinforce the hypothesis that a statistically adequate description for the Brazilian terms of trade involves a random-walkwith-drift model, with the presence of multiple breaks.

Considering that the estimated slope is statistically significant only at $6 \%$, a second restricted model was estimated, which corresponded to the local level model. In other words, a model that does not contain term $\beta$, but that allows for the presence of a stochastic trend. In this case, by omitting the cyclic component for simplicity, we have a random-walk-without-drift model, that is:

$$
\begin{aligned}
y_{t}=\mu_{t}+\eta_{t}, & \eta_{t} \sim \operatorname{NID}\left(0, \sigma_{\eta}^{2}\right) \\
\mu_{t}=\mu_{t-1}+\varepsilon_{t} & \varepsilon_{t} \sim \operatorname{NID}\left(0, \sigma_{\varepsilon}^{2}\right)
\end{aligned}
$$

\footnotetext{
${ }^{18}$ When estimating this model, all the breakpoints and the outliers encountered by the detection procedure were initially considered. Those that were not statistically significant were eliminated during the successive estimations.
} 
The Secular Trend of Brazilian Terms of Trade Revisited - 1850 to 2000

Table 4

Restricted Structural Model (2)

\begin{tabular}{lccc}
\hline Component & Coefficient & $t$ statistics & Probability \\
\hline Level & 4.6553 & 50.352 & {$[0.0000]$} \\
Slope & -0.00615 & -1.9096 & {$[0.0581]$} \\
Cycle & 0.0942 & - & - \\
Cycle & -0.1088 & - & - \\
& & & \\
Level 1888 & 0.2752 & 2.6413 & {$[0.0091]$} \\
Level 1913 & -0.3281 & -3.1049 & {$[0.0023]$} \\
Irregular 1919 & -0.3923 & 4.5152 & {$[0.0000]$} \\
Level 1922 & 0.4447 & 4.1059 & {$[0.0000]$} \\
Level 1930 & -0.4509 & -4.2470 & {$[0.0000]$} \\
Level 1950 & 0.5626 & 5.4057 & {$[0.0000]$} \\
Irregular 1954 & 0.2318 & 2.6620 & {$[0.0085]$}
\end{tabular}

Hyperparameters

r.m.s.e

$\mathrm{Q}$ ratio

Irregular

0.04886

0.6352

Level

0.03112

0.4056

Cycle

0.07692

1.0000

Diagnostic statistics

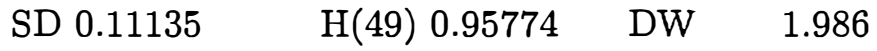
$\mathrm{r}(1)$
$-0.00300 \mathrm{r}(11)$
$-0.12032 \mathrm{Q}(11.10)$
$6.174[0.4593]$
$\mathrm{R}^{2}$
$0.8550 \mathrm{Rs}^{2}$
0.44850

Asymmetry $\mathrm{Chi}^{2}(1): 0.7858$ [0.3754] Kurtosis $\mathrm{Chi}^{2}(1): 0.1719$ [0.6784] Normal-BS Chi ${ }^{2}(2): 0.9577$ [0.6195] Normal-DH Chi ${ }^{2}(2): 0.9110$ [0.6341] Chow F(20,129):0.7120 [0.8080] CUSUM t(129):-0.1107 [1.0880] AIC:-4.2180 BIC:-3.9583

Statistics $\mathrm{H}(\mathrm{h})$ refers to the heteroskedasticity statistical test, statistics $\mathrm{r}(\mathrm{j})$ refer to the autocorrelations of the residuals, $Q(p, q)$ is the Ljung-Box statistics, D.W. is Durbin-Watson statistics, N-DH, Doornik and Hansen normality test, N-BS, Bowman and Shelton normality test. 
Sérgio Kannebley Jr. and Amaury Patrick Gremaud

Graph 2

Estimated Unobservable Components

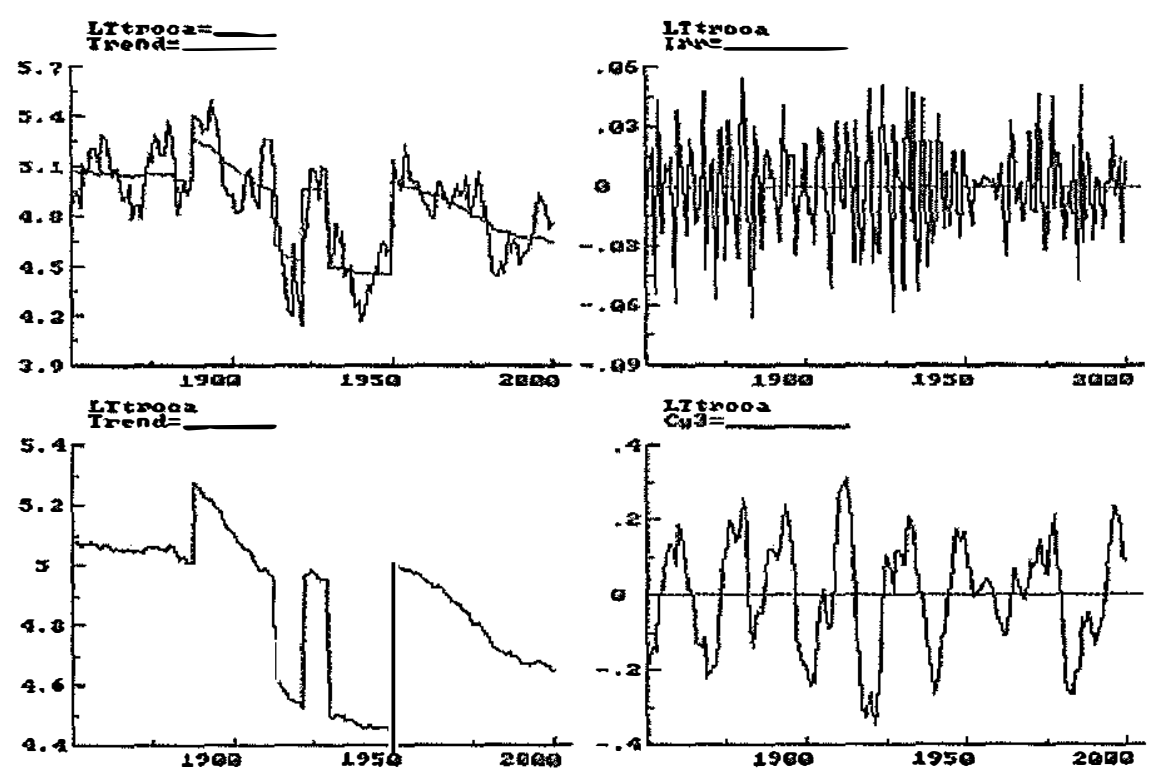

By following the same procedure adopted in the previous estimation, we used Harvey and Koopman (1992) procedure for the detection of outliers and structural breaks, whose periods are shown in Table 5. Notably, the omission of the slope parameter did not produce important alterations to the dates used by the procedure for the estimation of the local linear trend model, or to the magnitude of the breaks. The exceptions consisted of the breaks previously designated for the year 1888 and those detected for years 1915 and 1917. 
The Secular Trend of Brazilian Terms of Trade Revisited - 1850 to 2000

Table 5

Dates of Outliers and/or Structural Breaks

\begin{tabular}{|c|c|c|c|c|c|}
\hline Irregular & Value & Probability & Level & Value & Probability \\
\hline 1919 & 3.5772 & {$[0.0002]$} & 1913 & -2.3450 & {$[0.0102]$} \\
\hline 1921 & -3.3080 & {$[0.0006]$} & 1915 & -2.0672 & {$[0.0202]$} \\
\hline 1929 & 2.1619 & [0.0161] & 1917 & -2.1321 & {$[0.0173]$} \\
\hline 1949 & -2.0560 & {$[0.0207]$} & 1920 & -2.5671 & {$[0.0056]$} \\
\hline 1950 & 2.8151 & {$[0.0028]$} & 1921 & -2.0498 & {$[0.0211]$} \\
\hline \multirow[t]{4}{*}{1954} & 2.0813 & [0.0195] & 1930 & -3.1192 & {$[0.0011]$} \\
\hline & & & 1950 & 3.5420 & {$[0.0011]$} \\
\hline & Normal-BS & 6.418 & & Normal-BS & 6.656 \\
\hline & $\mathrm{Chi}^{2}(2)$ & {$[0.04]$} & & $\mathrm{Chi}^{2}(2):$ & [0.03] \\
\hline
\end{tabular}

Again, the best modeling, regarding the quality of the residuals and the predictive value within the sample is shown in Table 6 . Graph 3 shows the estimated components. The estimated stochastic cycle has a period of 19.57 years, corresponding to a frequency of 0.3210 . The level is stochastic, with the presence of multiple structural breaks. With regard to the model (2), which was previously estimated, the quality of the residuals is slightly lower, as some asymmetry is observed in the residuals and the CUSUM statistic has a greater magnitude, thus indicating a systematic deviation of the level estimated by the model in relation to the terms of trade series. However, the explanatory power of the models is practically equivalent. 
Sérgio Kannebley Jr. and Amaury Patrick Gremaud

Graph 3

Estimated Unobservable Components

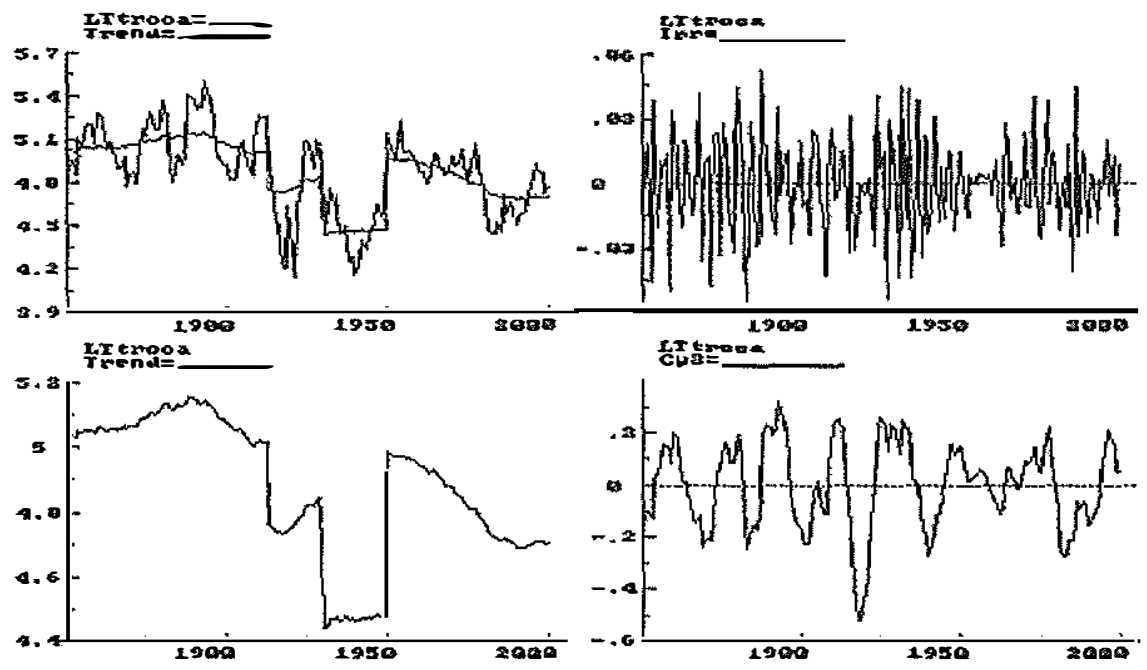

In order to make an additional comparison between these two rival models, tests were carried out to determine the predictability of the out-of-the-sample models. For this purpose, the models were estimated by restricting the sample to the years of 1970, 1980 and 1990. The predictive tests are step-ahead and extrapolative. The results of these tests are shown in Table 7 . As clearly observed, the predictive power of model (2) for both estimations in which samples are restricted to 1970 and 1980 is higher, whereas model (3) offers better prediction only for the estimation whose sample is restricted to 1990. Therefore, by considering the results for the predictive tests as well as the other diagnostic tests and the tests for adjustment capacity, it is possible to say that model (2) is better than model (3), corroborating the hypothesis of deteriorating secular trend for the Brazilian terms of trade. 
The Secular Trend of Brazilian Terms of Trade Revisited - 1850 to 2000

Table 6

Restricted Structural Model (3)

\begin{tabular}{lccc}
\hline Component & Coefficient & $t$ statistics & Probability \\
\hline Level & 4.7033 & 50.534 & {$[0.0000]$} \\
Cycle & 0.0508 & - & - \\
Cycle & -0.09363 & - & -
\end{tabular}

$\begin{array}{lccc}\text { Level } 1913 & -0.2572 & -2.5159 & {[0.0129]} \\ \text { Irregular 1919 } & -0.3799 & 4.38219 & {[0.0000]} \\ \text { Irregular 1921 } & -0.3390 & -3.9109 & {[0.0001]} \\ \text { Level 1930 } & -0.4525 & -3.9301 & {[0.0001]} \\ \text { Level 1950 } & 0.5072 & 4.9758 & {[0.0000]} \\ \text { Irregular 1954 } & 0.2314 & 2.6756 & {[0.0083]}\end{array}$

Hyperparameters

$\begin{array}{ll}\text { r.m.s.e } & \text { Q ratio } \\ 0.04488 & 0.5537 \\ 0.032746 & 0.4039 \\ 0.08106 & 1.0000\end{array}$

Diagnostic statistics

$\begin{array}{lrllll}\text { SD } 0.11401 & \mathrm{H}(50) & 0.5645 & \mathrm{DW} & 1.973 \\ \mathrm{r}(1) & 0.01229 & \mathrm{r}(11) & -0.0629 & \mathrm{Q}(11.10) \\ \mathrm{R}^{2} & 0.84801 & \mathrm{Rs}^{2} & 0.42178 & \end{array}$

$-0.0629[0.7642]$

Asymmetry $\mathrm{Chi}^{2}(1): 3.721$ [0.0663] Kurtosis $\mathrm{Chi}^{2}(1): 0.49093$ [0.4835] Normal-BS Chi ${ }^{2}(2): 3.863$ [0.1449] Normal-DH Chi ${ }^{2}(2): 3.552$ [0.1693] Chow F(20,130):0.72094 [0.7988] CUSUM t(130):-1.0095 [1.6852] AIC:-4.1971 BIC:-3.9774

Statistics $H(h)$ refers to the heteroskedasticity statistical test, statistics $r(j)$ refer to the autocorrelations of the residuals, $Q(p, q)$ is the Ljung-Box statistics, D.W. is Durbin-Watson statistics, N-DH, Doornik and Hansen normality test, N-BS, Bowman and Shelton normality test. 
Sérgio Kannebley Jr. and Amaury Patrick Gremaud

Table 7

Predictive Tests

\begin{tabular}{lllll}
\hline Sample & \multicolumn{2}{l}{ Onestep-ahead tests } & \multicolumn{2}{l}{ Extrapolative tests } \\
\hline & Failure test & CUSUM & AbsSum & SqrSum \\
1850-1970 & & & & \\
Model(2) & 23.8983 & -0.3912 & 19.6662 & 19.6025 \\
& {$[0.7766]$} & {$[1.3037]$} & & \\
Model(3) & 38.5773 & -4.0500 & 37.5859 & 64.638 \\
& {$[0.1355]$} & {$[1.9999]$} & & \\
$1850-1980$ & & & & \\
Model(2) & 13.6360 & -0.09215 & 14.9184 & 14.0972 \\
& {$[0.8485]$} & {$[1.0733]$} & & \\
$\operatorname{Model}(3)$ & 22.6391 & -3.38685 & 27.3892 & 47.4488 \\
& {$[0.3069]$} & {$[1.9991]$} & & \\
$1850-1990$ & & & & \\
$\operatorname{Model}(2)$ & 4.96794 & 1.22822 & 9.78911 & 12.2086 \\
& {$[0.8933]$} & {$[0.2214]$} & & \\
$\operatorname{Model}(3)$ & 3.58904 & 0.64565 & 5.62809 & 4.77048 \\
& {$[0.9640]$} & {$[0.5196]$} & & \\
\hline
\end{tabular}

* The predictive failure test uses the formula $\sum_{j=1}^{L} v_{T^{\prime}+j}^{2}$, is distributed similarly to a chi-square with $L$ degrees of freedom, in which $v_{t}$ is the standardized residual. **The test of CUSUM is given by CUSUM $t=L^{-1 / 2} \sum_{j=1}^{L} v_{T+j}$ and is arranged similarly to a $t$ distribution with $T-L-d$ degrees of freedom, in which $v_{t}$ is the standardized residual.

AbsSum is the sum of the absolute predictive errors whereas SqrSum is the sum of the squared predictive errors. 


\section{Final Considerations.}

The characterization of a country as peripheral is quite arguable due to the several processes of regional integration and economic development experienced in the last few decades by Brazil and other underdeveloped countries. However, the chronic external disequilibrium Brazil had to cope with during the 20th century at its several stages of economic development cannot be denied. Given this scenario, this analysis attempted to qualify one of the possible determinant factors of such disequilibrium, that is, the deteriorating secular trend of Brazilian terms of trade between 1850 and 2000 .

Historically, the presence of a cyclic pattern for Brazilian terms of trade is clear, albeit inconstant, until about the 1960s. This pattern was chiefly determined by the behavior of international coffee prices. After this period, this fluctuation pattern of the historical series becomes less evident on account of the changes to the Brazil's portfolios of imports and exports, in addition to the presence of strong and apparently transient oscillations produced by recessive economic policies and by the shocks to the market of some commodities, such as oil, in the 1970s and 1980s. Nevertheless, as far as the presence of a deteriorating secular trend is concerned, the historical data do not allow a direct conclusion, as many shocks occurred, especially at the end of the 19th century, seemingly until the mid-20th century, thus making a more accurate assessment of such evolution difficult.

Statistically speaking, we tried to improve the statistical representation of the terms of trade series, since part of the ambiguous results produced so far by the empirical literature on Brazilian terms of trade have been due to representations that were not sufficiently general, thus allowing the incorporation of several possibilities of representation for the trend component, in addition to structural breaks and/or outliers. 
This was possible through the estimation of structural time series models, where it was possible to infer about the presence of a negative deterministic slope term for the Brazilian terms of trade, in the 18502000 period, in addition to the presence of multiple structural breaks, referenced by the historical facts mentioned in the analysis. In opposition to this model, another model with only a stochastic trend and structural breaks was estimated. The comparison between diagnostic tests, adjustment quality and the predictive power between these models revealed the superiority of the negative term drift model, thus supporting the thesis about a systematic deterioration of the Brazilian terms of trade.

Submitted in May 2002. Revised in January 2003.

\section{References}

ATHUKORALA, P. 1993. "Manufactured exports from developing countries and their terms of trade: a reexamination of the SarkarSinger results" World Development, 21(10), 1607-1613.

BACHA, E.L. 1992. "Política Brasileira de Café: uma análise centenária" In: 150 Anos de Café, Marcellino Martins \& E. Johnston.

BARROS, A. R. 1992. "On the deterioration of the terms of trade for primary commodities" Revista de Econometria, Rio de Janeiro, 12(1), 31-55.

CUDDINGTON, J. T. \& URZA, C. M. 1989. "Trends and cycles in the net barter terms of trade: a new approach" The Economic Journal, 99, 426-442.

DELFIM NETTO, A. 1966. O Problema do Café no Brasil. São Paulo: IPE-USP. 
The Secular Trend of Brazilian Terms of Trade Revisited - 1850 to 2000

DARITY Jr, W. 1990. "The fundamental determinants of the terms of trade reconsidered: Long-run and long-period equilibrium". The American Economic Review, 80(4), 816-827.

DIAKOSAVVAS, D. \& SCANDIZZO, P. 1991. "Trends in the terms of primary commodities, 1900-1982: the controversy and its origin" Economic Development and Cultural Change, 39, 221-264. FAUSTO, B. 1989. "Expansão do Café e Política Cafeeira" In: FAUSTO, B. História Geral da Civilização Brasileira - Volume III: O período Republicano - tomo 1: estrutura de poder e economia (1889-1930). 5a. ed. São Paulo: Bertrand Brasil.

FRANCO, G.H.B. 1983. Reforma Monetária e Instabilidade Durante a Transição Republicana. Rio de Janeiro: BNDES.

FINDLAY, R. 1980. "The terms of trade and equilibrium growth in the world economy" The American Economic Review, 70(3),291-299.

1987. "Growth and development in trade models". In: JONES, R. W \& KENEN, P. B. (ed.) Handbook of International Economics, Amsterdam: North Holland, v. 1.

FURTADO, C. 1959. Formação Econômica do Brasil. São Paulo: Editora Nacional.

GONÇALVES, R. \& BARROS, A. C. 1982. "Tendências dos termos de troca: a tese de Prebisch e a economia brasileira - 1850/1979" Pesquisa e Planejamento Econômico, 12(1), 109-132.

GRILLI, E \& YANG, M. 1988. "Primary commodities prices, manufactured goods prices and the term of trade of developing countries: what the long run shows" The World Bank Economic Review, 2(1), 1-47.

HARVEY, A.C. 1989. Forecasting, Structural Time Series Models and the Kalman Filter. Cambridge, U. K.: Cambridge University Press. 
Sérgio Kannebley Jr. and Amaury Patrick Gremaud

HARVEY, A.C. \& KOOPMAN, S.J. 1992. "Diagnostic checking of unobserved components time series" Journal of Business and Economic Statistics, 10, 377-389.

IGLESIAS, R. 2001. "Baixo dinamismo das exportações de produtos industrializados ou baixo crescimento da produção industrial?" Revista Brasileira de Comércio Exterior, 67.

MARÇAL, E.F. 1996. "Paridade do poder de compra e a hipótese de raiz unitária: a evidência empírica brasileira" Revista LEP, Campinas, 3, 203-19.

KANNEBLEY, Jr. Sérgio 2002. "Desempenho exportador recente e taxa real de câmbio: uma análise setorial" Revista Brasileira de Economia, 56(3), jul./set., 429-456.

KRUEGER, A. 1997. "Trade Policy and Economic Development: how we learn" The American Economic Review, 87(1), 1-22.

PERRON, P. 1989. "The great crash, the oil price shock and the unit root hypothesis". Econometrica, 57, 1361-401.

PREBISCH, R. 1950. The economic development of Latin America and its principal problems. New York : UM - Economic Commission for Latin America.

RODRIGUEZ, F. \& RODRIK, D. 1999. "Trade Policy and Economic Growth: a skeptic's guide to cross-national evidence" NBER Working Paper $\mathbf{7 0 8 1 .}$

SARKAR, P. 1997. "Growth and terms of trade: A North-South macroeconomic framework". Journal of Macroeconomics, 19(1), Winter, 117-133.

SARKAR, P. \& SINGER, H. W. 1991. "Manufactured exports of developing countries and their terms of trade since 1965". World Development, 19(4), April, 333-340.

SINGER, H. W. 1950. "The distribution of gains between investing 
and borrowing countries". The American Economic Review, 40, May, 473-485.

1987. "Terms of Trade and Economic Development". In: EATWELL, J., MILGATE, M. \& NEWMAN, P. The New Palgravre: A Dictionary of Economics, The Macmillan Press Limited, 4, 626-628.

SOUZA, G. da S. 1984. "Sobre a validade da tese de Prebisch para a série de relações de troca da economia brasileira" Pesquisa e Planejamento Econômico, 14(2), 561-568.

SPRAOS, J. 1980. "The statistical debate on the net barter terms of trade between primary commodities and manufactures". Economic Journal, 90(357), 107-128.

1983. Inequalising Trade? Oxford, Claredon Press.

SRINIVASAN, T. N. \& BHAGWATI, J. 1999. "Outwardorientation and development: are revisionists right?" mimeo.

ZINI Jr., A. A. 1988. "Termos de troca e taxa de cmbio real no longo prazo", Anais do X Encontro Brasileiro de Econometria, SBE, 493-511.

ZINI Jr., A. A. \& CATI, R. C. 1991. "Cointegração e taxa de câmbio, testes sobre PPP e termos de troca no Brasil -18551990", Anais do XIII Encontro Brasileiro de Econometria, SBE, 559-579. 